\title{
Paracelsus - A Iatrokémia megjelenése az orvoslásban és a paracelán medicina alapjai
}

\section{Paracelsus - The appearance of iatrochemistry in medicine and the basics of paracelsic medicine}

\author{
dr. Madarász Bálint doktorandusz \\ Semmelweis Egyetem Népegészségtani Intézet \\ balintmadarasz1993@gmail.com
}

Initially submitted March 28. 2020; accepted for publication Apr.29, 2020

\begin{abstract}
The iconic alchemist figure of the 16th century: Philippus Aureolus Theophrastus Bombastus von Hohenheim or commonly known as Paracelsus is surrounded by many mystics and misconceptions. This study aims to provide a short summary about Paracelsus' medical concepts. Thus it is an attempt to understand Paracelsus' chemical interpretation of health and disease and their possible explanations.

My work was based on Karl Ed Rothschuh's Paracelsus interpretation: Konzepte der Medizin in Vergangenheit und Gegenwart, supplemented with a number of other primary and secondary sources. I have reviewed the essence of iatrochemistry, the scientific views of Paracelsus, his theories about diseases, and his methods of therapy.

He may have discovered more about many things than people might have thought in his era, but of course it is possibly just our present days' interpretation from the genetic code to the emerging theory of psychosomatics. Undeniably, he had new revolutionary ideas indeed while anticipating later ages however, full understanding was unfortunately hampered by his particular style and inconsequent use of terminology. Paracelsus has an enormous oeuvre and the present study does definitely not provide the right opportunity to full processing.
\end{abstract}

Kulcsszavak: Paracelus, orvostörténet, tudománytörténet, mikrokozmosz, makrokozmosz, pszichoszomatika, iatrokémia

Keywords: Paracelsus, medical history, history of science, microcosmos, macrocosmos, psychosomatics, iatrochemistry

\section{Bevezetés}

A iatrokémia alatt egy olyan orvosi elméletet értünk, amely szerint a fiziológiás jelenségek, az egészség és a betegség, kémiai folyamatokkal magyarázhatók. Ez a modell tette lehetővé a növényi gyógyszerek alkalmazása mellett az ásványi és kémiai úton előállított gyógyszerek kifejlesztését és elsőkénti belsőleges (per os), gyógyászati célú felhasználását. [1]

E szemlélet létrejöttéhez feltételeznünk kell egy kellöen magas jártasságot és a megfelelö tudást az anyagok alkotóelemeiről, alapos ismérveiről, jellemzőről, egyedi tulajdonságaikról, egymástól való különbségeiről és a hasznosíthatóságukról. Továbbá szükségesek a nyersanyagok és a tisztított szubsztanciák gyakorlatban való előállítási és kezelési ismerete, melyek elsősorban hevítés felhasználásra épülő technológiák, mint például olvasztásos, kivonásos, desztillációs, vegyítési, laboratóriumi módszerek és azok vizsgálati, gyakorlati tudásra és tapasztalatokra alapuló eljárásai.[2] 
Kaleidoscope

A szükséges technológiai ismeretek az ókori Egyiptomban már megjelentek, majd később az iszlám világba is átkerültek, ahol jelentős tudást halmoztak fel e folyamatokról. A keresztény Európában fokozatsan a 4-15. századig gyarapodott nagymértékben ez a tudás föként arab közvetítésre. Az alkímiai eljárásokon túl az ősidők óta léteztek ismeretek pl. vas, ón, cink, arany, ezüst, réz kinyerésére a megfelelő olvasztásos eljárásokkal, de ide sorolhatjuk még a sók bányászatát is, mint például kősó, szóda, valamint kén és salétrom kinyerését is vagy akár az üveg készítés módját is.[3]

Az anyagelméletekből, a laboratóriumi alkímiából és technológiákból fokozatosan növekedő tudás- és ismeretanyag tette lehetővé tehát iatrokémiai elképzelések megszületését a XVI-XVII. században, amelyet két fö anyagelméleti megközelítés, befolyásolt: [4]

$\mathrm{Az}$ arisztotelészi vélekedés szerint az anyagot el kell választani az anyag tulajdonságaitól (hülémorfizmus tana). Az anyag felépítését (filozófiai értelmezésben) úgy képzelte el, hogy három részböl áll: elvont fogalomból, formából és mozgásból. .Az anyag elvont fogalmi léte a hülé, ami a lételvet jelöli. A morphé, a forma a felelős egy konkrét anyag tulajdonságaiért. Az újonnan létrehozott új tulajdonságokkal rendelkező anyagok az új formájuknak köszönhetik új tulajdonságaikat, az érzékelhető létezők változását pedig a mozgás okozza, ami a változás maga. Az anyag végső alkotóelemei a négy alapelem, nevezetesen a tüz, a víz, a levegő és a föld. Ezeket a négy alapvető tulajdonság (meleg, hideg, száraz és nedves) hozza létre. Meghatározzák az anyag viselkedését, súlyát, fizikai állapotát és hatásait. Az anyagok előfordulhatnak önmagukban, vagy kapcsolatban (vegyesen) vagy keverékként (szintézis). [5][6]

A másik szemlélet az Egyiptomban született alkímiai nézet. Ezt a legendás Hermész Triszmegisztosztól (Háromszor-legnagyobb Hermésztől), Hermész egyiptomi reinkarnációjának tartott bölcstől eredeztetett tudást tartották az alkimisták ismereteik és inspirációik legfőbb forrásának. Hermész müvészetének és annak müvelőre az elzárkózás és titkolózás gyakran jellemző volt. Egy titkos és titokzatos müvészet, amely szimbólumok, képek és analógiák alapján müködik, az anyag fogalmi-logikai elképzelése helyett. [7][8]

Az alkímia az emberi lélek tökéletességével foglalkozott. Hasonlatosan a keresztény egyházhoz, ami (Szent) Péterre, Isten kősziklájára épült úgy az alkímia tudománya pedig a bölcsek kövére. Elképzelésük szerint ennek birtokában meggyógyíthatók lesznek a betegségek, meghosszabbítható az élet. Munkásságuk során szüntelen, ezt az ismeretlen és rejtélyes anyagot(?), formulát(?) vagy képletet(?) keresték. Úgy vélték, hogy abból származhat az élet elixírje. A kő utáni kutatás során az alkimisták laboratóriumaikban számos anyagot és azok kölcsönhatásait megvizsgálták, ezzel pedig olyan tudásra tettek szert, ami végül egészen a kémia, a kohászát és a gyógyszerészet tudományának megszületéséhez vezetett.[9]

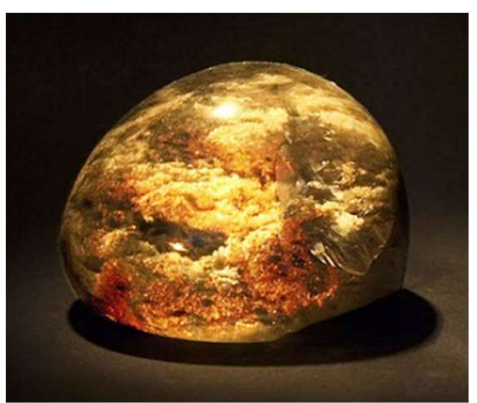

\section{1. ábra Illusztráció: Egy elképzelés a bölcsek kövéröl ${ }^{1}$}

Az i.sz. 8. századtól a sevillai Geber hatása nyomán uralkodó nézetté vált az alkimisták körében hogy két princípium a meghatározó a fémek tulajdonságaiban: a higany (hideg és nedves) és a kén (forró száraz), de

\footnotetext{
${ }^{1}$ (Forrás: http://3.bp.blogspot.com/-vpP4vFxBaxA/TVT3gFRAckl/AAAAAAAAAC0/AiN6_GiTvhg/s1600/The-PhilosophersStone.jpg 
Kaleido scope
Journal of History of Culture, Science and Medicine
2020. Vol. 10. No. 20.

e-ISSN: 2062-2597

DOI: $10.17107 /$ KH.2020.20.17-29

nem, mint építőanyag, hanem sokkal inkább, mint alapelv. Ennek értelmezése, hogy a fémek fényessége/csillogása és olvaszthatósága a "filozófiai" higany természetén, míg a színe és gyúlékonysága a "filozófiai" kénen múlik. Tehát ez nem a kémia alkotóelemekre utal, hanem filozófiai megközelítése az anyagok tulajdonágainak leírására. A geberi elméletet Basilius Valentinus a 15. század neves alkimistája vitte tovább kibővítve a sóval, mint 3. princípiummal.[8Hiba! A hivatkozási forrás nem található..][10][11][12]

Egészen a 15. századig az alkímia továbbra is a fémek arannyá történő átalakításáról és a „bölcsek kövének" megtalálásáról szólt. Az állandó kutatás során azonban fokozatosan sok olyan anyagot találtak, amelyek bizonyos technológiák alkalmazása mellett rendszeresen eloállíthatókká váltak, és, amelyek elég izgalmasnak ígérkeztek a további kísérletezésre és új vizsgálatokat indítására.[13]

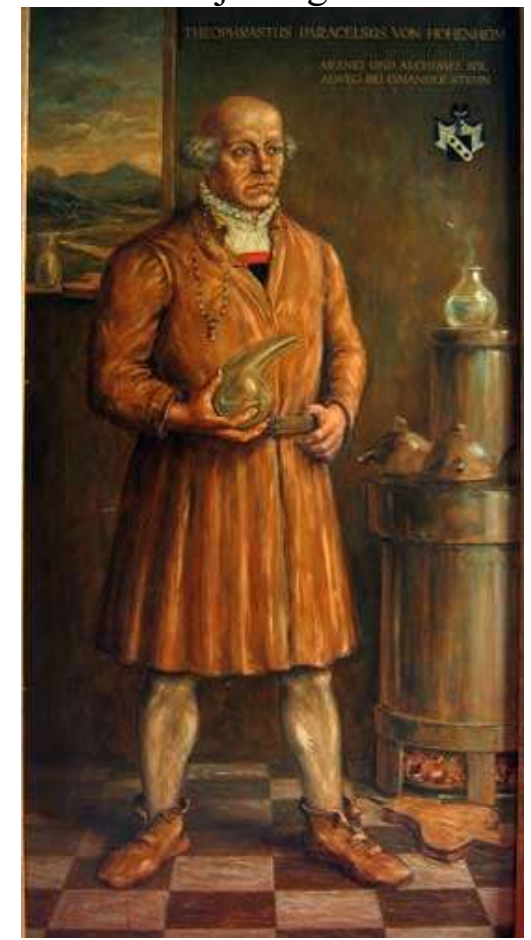

\section{2. ábra F. Görtitz: Paracelsus, (1935) ${ }^{2}$}

Philippus Aureolus Theophrastus Bombastus von Hohenheim, avagy Paracelsus (1493-1541) ifjúsága kezdetén svájci és ausztriai bányásziskolában és bányákban tanulmányozta alaposan, az e helyeken használt technológiai müveleteket, valamint az alkímiai folyamatok eredményeit és értelmezéseit. Legfôbb tanítói Lavant és Freising püspökén kívül saját édesapja, a helyi bányaorvos volt, aki elméleti és gyakorlati kémiára oktatta. De tanult később Bécsben, Baselben és Ferrarában is. Ezen kívül tanulmányútjai során szintén tovább bővítette tudását. Sokan már életében imposztornak és közönséges csalónak tartották. Ennek az oka valószínüleg a tudományos munkáiban sokszor ködös és zavaros paracelsusi terminológiájának használata és sajátos stílusa, amivel kortársait keményen bírálta mind müveiben, mind pedig nyilvánosan. Ami azonban bizonyos, hogy annyira ismerte és oly nagy hatást gyakorolt rá alkímiai tudása, hogy azt, megtette orvostudományi elméleteinek alapjává.[14][15][16]

]

\footnotetext{
2 (Forrás: https://1pvx212tsjxq5z6yc4a59yw8-wpengine.netdnassl.com/images/All_journal_images/2015_Briefs/Sonoc/Sonoc3.jpg) 
Kaleidoscope

\section{Paracelsus koncepciója}

Paracelsus csak részben volt eredeti vagy új eme tekintetben, ugyanis a filozófiai, az orvosi asztronómiai és a mágikus tanok már ősidők óta részét képezték természetfilozófiának, az akkori orvoslásnak. [17] Az újítása abban rejlik, hogy Paracelsus szorosan összekapcsolta egy rendszerbe a természetfilozófiáját, az asztronómiai ismereteit és az alkímiai tudását, ezzel létrehozva egy hármas egységet. Egyedi szemléletével és tudásával így megalapozta a iatrokémiát és bizonyos értelemben a mai receptor elmélet alapú orvoslás fundamentumait is lefektette. Ráadásul ezt még kiegészítette egy negyedik, nagyon fontos (korát megelőző) elemmel, nevezetesen pedig a jellemmel, mely a gyógyítást végző személy helyes szemléletét és viselkedését írja elő. Ezt a négy pillért összefogva és egyesítve építi fel új orvosi elképzelését. Az 1530-ban írt és 1565-ben nyomtatott "Paragranum" könyve foglalkozik a paracelán orvostudomány- és ennek természetfilozófiai alapjaival. [18]

Sajnos, arról azonban nem beszélhetünk, hogy ez egy teljesen egységes, jól megszerkesztett medicinális irányzat lenne. Paracelsus fö ötletei, és az azokból levont következtetései nem egy alaposan kigondolt teljes rendszer részei, hanem nagyszámú írásaiban és azok átirataiban szereplő gondolatok gyüjteménye, melyek között gyakran évtizedes különbségek vannak. Szövegezésben és a megfogalmazásban gyakran eltérések és ellentmondások találhatóak. Egyes dolgok nem egyértelmüek és nem illeszkednek egymáshoz. Ezek fényében nem kis kihívás a paracelsusi életmüvet rendezni és értelmezni.[17]

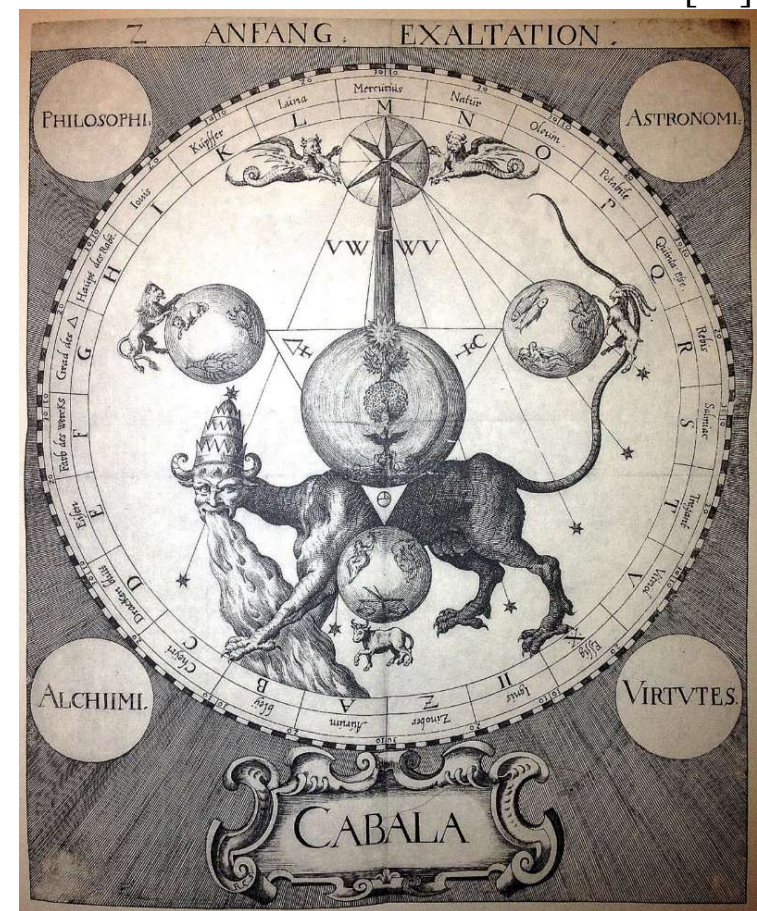

\section{3. ábra Az orvoslás paracelsusi fundamentumai ${ }^{3}$}

A paracelsusi természetfilozófia alapgondolata a makrokozmosz (az elemek, csillagok, bolygók és az emberek földi környezete növényekkel, állatokkal, ásványi anyagokkal) egyetemes egységének és egyetértésének a mikrokozmosszal, azaz az emberrel való kapcsolatának elve. [17]

Az alapgondolat lényege és alapja, hogy a kozmosz és a természet Isten müve akárcsak az ember, így ami ott megtalálható nagyban, az kicsiben, az emberben is meg kell, hogy legyen. Nincs olyan az univerzumban, ami ne lenne meg az emberben is.[17]

${ }_{3}^{3}$ (Forrás: https://i.pinimg.com/originals/b1/f9/18/b1f91814cc7735d9fe0acfcbe1d155b4.jpg) 
Kaleidoscope

Paracelsus továbbá összhangban a keresztény nézetekkel, állította, hogy az embert a világ teremtésekor Isten utoljára alkotta meg a Limus terraeből (az Ösföld egy darabjából). Abból az anyagból, amiből korábban az ég, a csillagok, állatok és bolygók is létrejöttek. Következtetése szerint így tehát minden ugyanabból van, vagyis ugyanaz a rendszer érvényes mindenre. Ebből a szemszögből nézve igaza is van, hiszen az univerzumot alkotó azonos elemekből és azok atomjaiból épül fel az ember is.[19][20]

$\mathrm{Az}$ emberi test működését a makrokozmoszból való eredet alapján értelmezte. Ezért hasonlóságokat és összefüggéseket vélt felfedezni a makrokozmosz (teljes fizikai világ) és a mikrokozmosz (test belső világa) között. Ezt pedig nem csak anyagi, de pszichikai értelemben is így értelmezte. [17]

Paracelsus úgy vélte az egyes égitestek (nevezetesen: Nap, Hold, Mars, Merkúr, Vénusz, Jupiter, Szaturnusz) megfeleltethetőek a mikrokozmosz fő szervrendszereinek, a közöttük lévő kapcsolat miatt. Feltételezte továbbá azt is, hogy a kozmoszban minden struktúra tartalmaz egy az anyaghoz tartozó szellemi részt is. Ez utóbbi az ,asztrális”, láthatatlan partikulum.[18]

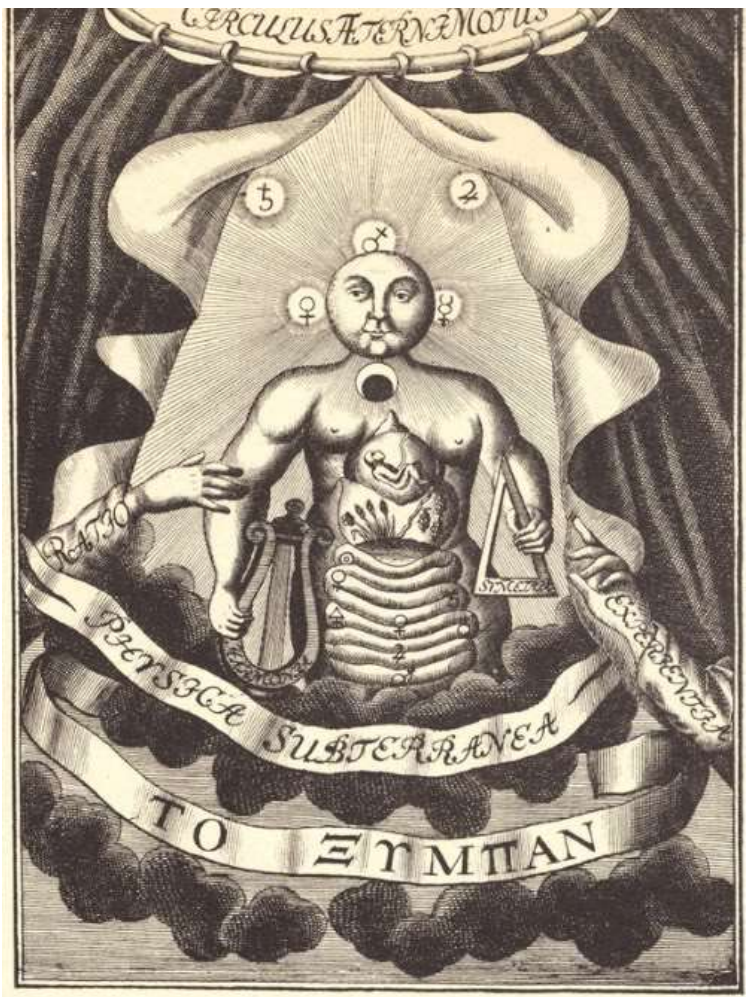

\section{4. ábra Illusztráció J.J. Becher's Physica Subterranea címü müvéből ${ }^{4}$}

Az anyagok vagy matériák a négy elemből: tűzből, földből, vízből, levegőből és a müködési elvből, a kvintesszenciából állnak. Ha ezeket metaforaként tekintjük az élőlény vagy "élőanyag" esetén, akkor úgy is mondhatnának, hogy ezek az elemek: az entalpiának/energiának, (biogén) elemeknek, víznek, térnek/légköri gázoknak, valamint a, tudatnak/léleknek feleltethetőek meg. Paracelsus a kvintesszenciát az anyag a legtisztább és leghatékonyabb részének tartotta. Kinyerésük alkímia müveletek és a tüz segítségével lehetséges. Ez lehet például oldás, olvasztás, forralás, desztillálás, pörkölés, szublimálás stb. Ezek az eljárások mechanikusan és kémiailag is elválasztják a matériát, megtisztítják a szennyeződésektől is

${ }^{4}$ (Forrás:https://1.bp.blogspot.com/__V9YUthwE9Y/T50PFSitxul/AAAAAAAABIY/H0WVgmZsB6A/s1600/rato-1.jpg) 
Kaleidoscope

valamint a láthatatlan erőket is felszabadíthatnak. Így nyerheti ki az ember az Arkánumot a kvintesszenciáját az anyagnak, a müködtető és lényeget adó eröt. [17][21]

Az alkimisták kísérleteik során számos alkalommal használtak desztillációs eljárásokat. Hieronymus Brunschwig (1450-1512) alkimista, 1500-ban különleges munkájában (Liber de arte distillandi de simplicibus) emlékezett meg róla. Az alkímiai müveletek és a melegítés során három elválasztható részt figyelt meg. [17]

1. Azt, ami éghető és tüzveszélyes, pl. olaj, fa vagy a kén. Ezt az éghető anyagot az alkimisták "kénnek" nevezik (filozófiai kén minden, ami ég).

2. Az égés vagy a melegítés maradványai a hamuban, a Sal - a só. (Ez a filozófikus só, mint kifejezés az összes megfigyelhető szilárd maradék anyagra).

3. Az, amely nem ég, és nem marad a földön, de még mindig füstben van, majd lecsapódik és újra megjelenik a hideg falon, azaz szublimált, ez a "Mercurius", azaz: a higany.[17]

E három kifejezésnek semmi köze sincs az azonos nevü anyagokhoz azok csak mintául szolgáltak a csoportok megalkotásához és elnevezéséhez. Míg az alkimisták ezt csak az elsődleges alkímiai alkotóelemek meghatározójaként tartották számon addig Paracelsus ezt kiterjesztette, az összes fizikai szerkezet alapelveivé. Ezek megtalálhatók minden testben, mindegyik eltérő típusú és összetételü. Meghatározó tényezője nemcsak a fémeknek, de minden növénynek, állatnak, ásványi anyagnak, ételnek, de még az embernek is. [11][17]

Itt egy látszólagos ellentmondást találhatunk. Az elemek és a princípiumok létezése ugyanis nem zárja ki egymást. A három paracelán alapelv - a só, a kén és a higany - nem helyettesíti az elemeket. Sokkal inkább az anyag tulajdonságait határozzák meg: a só felelős a szilárdságért, a kén a gyúlékonyság és zsírosság állapotáért és a higany a füstös/gözös, folyékony és illékony állapotáért. A négy elemre pedig inkább építőanyagként kell gondolni. [22]

Az ember felépítését a paracelsusi vélekedés szerint a csíra határozza meg, amihez az építőanyagot a test az élelemmel veszi magához. -E folyamatot felfoghatjuk úgy is, mint egyfajta megközelítését a ma már ismert genetikai kódnak.- Paracelsus szerint a test pedig maga is egy alkimista laboratórium, ahol különböző anyagok feldolgozása, átváltozása jön létre, azon belül is különösen a gyomor a legaktívabb. Vélekedése szerint az ételt a három alapelv szerint szétbontja és az emésztés során elválasztja egymástól a jót és a rosszat. A hasonló vonzás szerint a ,jó” a gyomorból a végtagba vándorol, és ott „hússá” válik. A rosszat pedig ki kell választani, mert a betegség csíráját hordozza.[17][23].

Paracelsusnál tehát az alkímia többé nem egy titkos tudomány, melynek célja a bölcsek kövének keresése vagy arany készítés, hanem egy tudomány a természetes testek összetételéről és müködési módjáról, beleértve az emberi testet is. Ezen alapszik nála az egészség és a betegség értelmezése, és ez motiválja az alkímiai alapelvek alkalmazásánál a hatékony, specifikus gyógyszerek előállításánál is.[17]

Iatrokémiának nevezhetjük tehát a kémiai alapokra helyezett, elméleti és gyakorlati orvoslást, amely kémiaialkímiai folyamatok segítségével alkalmas gyógyszereket képes előállítani.[17].

\section{Paracelsus iatrokémiai betegség elmélete}

Paracelsus a betegségeket fizikai és lelki eredetűekre osztja és ezzel pszichoszomatika csírájának megjelenéséröl is beszélhetünk![24]

Tagadja a korábbi humorálpatológiai megközelítést, miszerint a test különböző nedveinek állapota felelős a betegségek kialakulásaiért. Paracelsus szerint a kórok mindig a mikrokozmosz egészét érintik. Úgy tartja, ha a test szenved, a léleknek ettől még nem szükséges, azonban ha a lélek szenved, akkor a test is szenvedni fog, vele egyetemben. Öt entitást (enst) különböztet meg a betegségek okaiként. Az első három anyagi entitás a testet, míg az utolsó kettő a spirituális részt, a lelket támadja.[17][25] 
Kaleido scope Müvelődés-, Tudomány- és Orvostörténeti Folyóirat Journal of History of Culture, Science and Medicine
2020. Vol. 10. No. 20.

e-ISSN: 2062-2597

DOI: $10.17107 /$ KH.2020.20.17-29

Ens Astrale A makrokozmikus világ, amely körül vesz bennünket és az abban létező ember (mikorkozmosz) kapcsolatán alapuló betegségek.[25]

A makrokozmoszból annak mintájára és annak anyagából létre jött a mikrokozmosz. Ha a makrokozmosz beteg és zavart, akkor a mikrokozmosz is az lesz. Ahogy fentebb is tárgyaltuk a makrokozmosz és mikrokozmosz párhuzamban áll egymással a teremtés miatti hasonlóságok alapján. Ezért az egyes égitestek és szervrendszerek között kapcsolatokat feltételez Paracelsus. Úgy véli valamilyen úton a csillagok kigőzölgéseik, és sugárzásaik révén fejtik ki hatásaikat a szervezetben lévő, analóg szerveikben zajló folyamatokra. Ebben az esetben a betegségek a csillagok után is elnevezhetőek. [18]

Ens Veneni a mérgező vagy nem kellően tiszta szubsztanciák által okozott kórok. Minden olyan betegség, amely az Ens Veneni-ből származik, a rothadó anyag emésztéséből következik. Ha az emésztés megsérül, akkor a legföbb alkimista, a gyomor, már nem tudja tökéletesen elvégezni a jó és a rossz elválasztását és a mérgek kiürítését a kiválasztó szerveken keresztül, ezzel megnyitva az utat számos betegség kialakulásának.

Ens Naturale hajlamokból származó betegségek, amik az emberből magából fakadnak.

Ens Spirituale- pszichológiai és pszichoszomatikus kórok melyek a belső spirituális erőnkből és a gondolatainkból születnek

Ens Deale, a sorsszerü (karmikus) vagy isteni eredetü betegségek csoportja.[23][25]

A betegségek a három princípium (kén, higany és só) szervezetbeni nem megfelelö aránya miatt jöhetnek létre. Tehát a három alapelv harmonikus egyensúlya kulcsfontosságú. Paracelsus szerint egyes betegségért a kén túlsúlya, másokért a higany, megint másokért a só túlsúlya lehet a felelős tényező. (hangsúlyozandó hogy ezeket filozófiai elemekként kell értelmezni) Tehát a különböző eredetü betegségek a három princípium arányát változtatják meg, ezért manifesztálódik a betegség. [17]

Bizonyos hasonlóságokon alapuló megfigyelések vezettek el valószínűleg ezekhez a megállapításokhoz: A kén, mint anyag, gyúlékony, hőt ad és változni képes. Ezen párhuzamra felépítve a filozófiai kén például a láz, pestis forrása lehet. A színe sárga, ezért sárgaságot okozhat.[17]

A só vonzza a vizet, higroszkópos, ezenkívül pácolással megakadályozza a hús rothadását. A bomló szerves anyag vizet enged ki magából, tehát a különválasztás következményeként jöhet létre az ödéma is. Egyes elfogyasztott sók is hasmenést okoznak, (ozmotikus hashajtók müködési elve), tehát a hasmenést a szervezetben lévő só is okozhatja. Ha a test elveszíti a sót, lecsökken az izmok ereje, és csontjainak stabilitása is. Sóoldatokból üledékként kristályok válhatnak ki. Ha ez a testben történik úgy, mint a borkő a raktározott borban, akkor a testfolyadék besürüsödik és kiválás jön létre: például ahogy vese vagy a hólyagkő esetén. A só tehát elzáródásokat, székrekedést vagy hasmenést, köszvényt, duzzanatot, és keményedést okozhat. [17]

A tömény só helyi bőr elváltozásokat generálhat, károsíthatja a szövetet és váladékozó fekélyek kialakulását idézheti elő. Külső sóbetegségnek tartotta még a leprát, a rákot, a szemölcsöket. Belső sóbetegségnek tartotta például a légzési elégtelenségeket, a tbc-t, köhögéseket, de a pleuritiszt is.[17]

A test higany része hajlamos arra, hogy felszálljon, és kicsapódjon. Ahol elkülönül, és nem tud menekülni, leesik, majd például melankóliát, mániát, őrültséget (vesaniát), encephalitist, meningitist vagy szélütést okozhat.[17] 

Kaleido scope
Journal of History of Culture, Science and Medicine
2020. Vol. 10. No. 20.

e-ISSN: 2062-2597

DOI: $10.17107 /$ KH.2020.20.17-29

Alkímiai tapasztalatai (bányákból, és laboratóriumokból) alapján egy másik észrevételt is tett Paracelsus: csakúgy, mint a fémfeldolgozásban a színek változása (pl. tinktúrák) alapvetően megmutatják a transzmutáció mértékét, vagyis a fémfeldolgozásban a színek sokat elárulnak a fémekről, ami alapján úgy vélte a betegségek esetén is fontos dolgokat jelölhetnek ezek a változások. Tehát az elszíneződések mértéke az embereben is indikátorként szolgálhatnak számos betegség és fontos élettani folyamat esetében.[17]

\section{Paracelsus iatrokémiai terápiája}

Paracelsus nem tekinthető a kémiai „orvosság” feltalálójának, ám reformerének annál inkább. Külsőleges használatra már Dioszkoridész (i.sz. 40-90) is ajánlotta például a réz-szulfátot $\left(\mathrm{CuSO}_{4}\right)$ adsztringensként, rüh ellen, valamint antimon-szulfidot kinőtt vadhús ellen és fekélyek kezelésére. Arnald van Villanova (1240-1311) higanyt javasolt bőrbántalmakra kenőcs formájában, de hasonló formában szifilisz ellen is felhasználták. Az 1485-ben megjelent Hortus Sanitatis pedig említést tesz az antimonszulfid $\left(\mathrm{Sb}_{2} \mathrm{~S}_{3}\right)$ aranyér ellen használatára vonatkozóan, azonban minden ilyen jellegü felhasználás külsőleges volt és főként sebekre, sebgyógyszerként használták. Paracelsus újítása tehát ebben volt, ezt változtatta meg, Ö volt ugyanis az első, aki másként, belsőlegesen (per os.) használta fel ezeket a vegyületeket gyógyszerként.[11][17]

Általában nem a durva kémiai anyagok használatát támogatta, hanem ezek tisztítás útján nyert legfinomabb formáit. Ezek a kémiai szerek maguk voltak a hatóanyagok vagy tiszta hatóerők: arcanák. Paracelsus koráig a kémiai anyagokról azt gondolták, hogy azok belsőleg használva mérgezőek.[17] Ám a Mester paradigmaváltásával ez a szemlélet megváltozott. Ahogy a hírhedté vált mondatában is hangzik:

„Alle Dinge sind Gift, und nichts ist ohne Gift; allein die dosis machts, daß ein Ding kein Gift sei." Minden méreg, semmi sem létezik mérgek nélkül, egyedül a dózis teszi, hogy egy dolog mérgezö-e. [26]

Ezen kívül elvettette a contraria contrariis elvet (az okkal ellentétes gyógymód használatát), terápiájában a hasonlót a hasonlóval koncepciót követte inkább, ám a dózis körültekintő megválasztásával![27Hiba! A hivatkozási forrás nem található.]

Ha Paracelsus egy új orvosságot talált, ilyenkor analógiái alapján következtetéseket vont le, a mikro- és a makrokozmosz közötti kapcsolatokról és a gyógyszere használhatóságáról, miközben az asztrális összhangot is kereste. [17]

A belsőleges terápiái elkészítéseben a szignatúratan, jelentős szerepet játszott. E tézis lényege azon a feltételezésen alapul, hogy a természetben a forma és szín is utal arra, melyik növény használható gyógyászati célból, adott betegségre (pl. májproblémákra a májfü, mert lebenyes felépítésủ levele hasonlít a májra). E tan fö úttörője Paracelsus volt, bár a paracelán orvos-alkimistát Oswald Crollt (1563-1609) nevezhetjük igazán csak a mesterének. A szignatúratan hosszú időre az alapvető orvosi ötletek és feltételezések részévé vált, és teljesen azóta sem tünt el. Még manapság is bizonyos népi orvoslási eljárásokban mindig szerepet játszik.[27][29]

Ennek alapján jutott arra a felismerésre is Paracelsus, hogy ha bizonyos szubsztanciák, külsőlegesen, fekélyek ellen hatásosak, akkor ezeknek a szereknek belső fekélyekre belsőlegesen felhasználva is effektívnek kell lenniük. Ezért például Paracelsus higany arkánát javasolt ilyen esetben kezelésként, amit például egy Mercurius Vitae nevü vegyület vagy keverék tartalmazott, többek között feltehetőleg higany és antimont összetevőkkel.[17][30]

Véleménye szerint az arkánum asztrális összhang útján bejut a beteg testrészbe, ezután a gyógyszer eltávolítja a szennyeződést, és megerősíti a megzavart három elv közötti kapcsolat tisztaságát. [17] 
Kaleido scope
Journal of History of Culture, Science and Medicine
2020. Vol. 10. No. 20.

e-ISSN: 2062-2597

DOI: $10.17107 /$ KH.2020.20.17-29

A Paracelsus által készített elixírek nem csak alkoholos növényi kivonatok, de kémiai eredetủek is lehettek pl. Elixir salis. Minden tisztított anyag, jobban behatol, vagy hatékonyabb, mint a tisztítatlan. A legtisztább pedig a kvintesszencia. Nem nyers vagy egész gyógyszerként alkalmazott készítményeket, hanem a kifejezetten a hatékony esszenciájukat, amelyeket kémiai technikákkal, vízzel vagy alkoholos kivonások révén feloldással, tisztítással, szublimálással, desztillációval, melegítéssel nyert ki. A monoterápiák alkalmazását tartotta helyesnek. Úgy gondolta az orvosnak be kell fejeznie a körülöttünk lévő gyógyszerek vagy arkánumok tisztítását, és használhatóvá kell tenniük azokat. [17][18]

A paracelsusi kémiai gyógyszerek palettáját számos vegyület gazdagította, úgymint: réz-szulfát, arzén vegyületek, aranyklorid, kálium-szulfát, bizmut és ónvegyületek valamint ólom készítmények pl. lac. virgineum (ólom-acetát és vizes sóoldat keveréke), Crocus Martis (vas-oxid), ez égés és rothadás gátló volt, de alkalmazta ödéma kezelésre is.[17][31]

Az alkímiai eljárások átvitelét az orvoslásba jól példázza az antimon esete. Ugyanis az alkimisták az arany és ezüst keverékek szétválasztására használták, tehát az értékes, a jó és a rossz kettéválasztására. Ebből tehát azt a következtetést vonta le Paracelsus, hogy nem lenne-e hasznos az egészség és a betegség elválasztására is? [17]

Bizonyos szervetlen savak feloldják a sókat, Paracelsus ugyanezt a hatást tulajdonította a savas ásványvizeknek is, amelyek képesek köveket feloldani így ezeket is belsőleges használatra írta elö. Speciális gyógyszere volt még az un. Magisterien keverék, mely gyöngyökböl, korallokból, fémekböl, borostyánkőből, olajokból, növényekből és vérből származó kivonatokból állt.[17]

A „kémiai eredetư” gyógymódjain túl Paracelsus a növény- és állatvilágból származó összes szokásos gyógyszert is felhasználta, különösen a fiatalabb éveiben. Ezen kívül úgy tartotta, hogy bizonyos gyógyító képességek a halál után is megmaradhatnak a maradványokban. pl. múmiák esetében.[17]

A paracelsusi orvosi koncepció tehát az ember, a természet, a betegség és a gyógyulás szoros kapcsolatán nyugszik, a makro és mikrokozmosz közötti analogikus rendszerben elhelyezkedve. Számos hasznos, új megfigyelést és kémiai tapasztaltot emelt be ebbe az új szisztémába. Az bizonyos, hogy nem egy szigorú, logikus részletesen alátámasztott rendszert hozott létre, ám ennek ellenére is lenyügözö így is, hogy számos ponton korát meghaladott forradalmi gondolatai voltak.[17] 
Kaleidossope

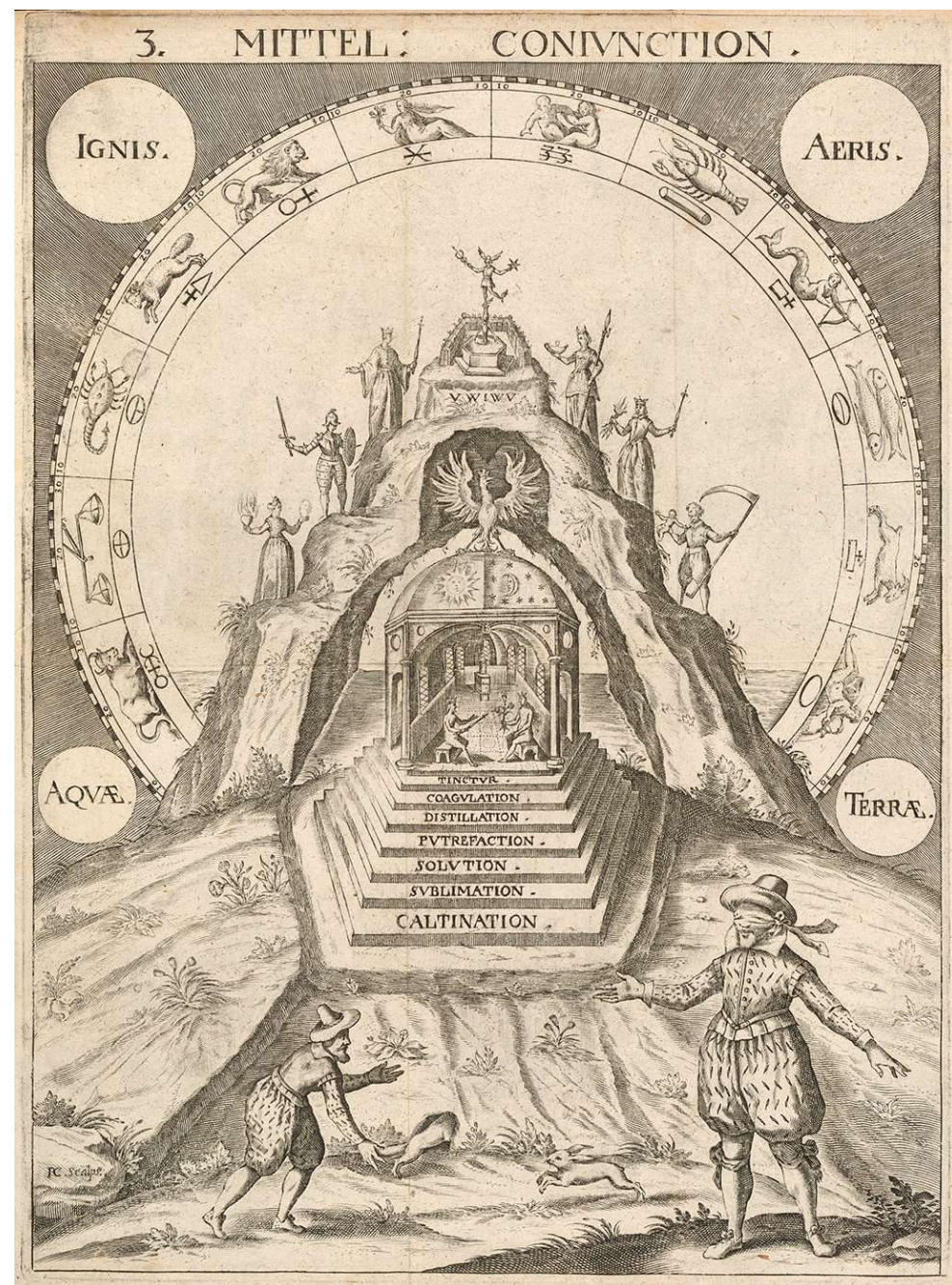

\section{5. ábra Illusztráció: Conjunction, Raphael Custos. 1633. Steffan Michelspacher, Cabala, Spiegel der Kunst und Natur in Alchymia ... [Cabala, The Mirror of Art and Nature in Alchemy] (Augsburg, $1663)^{5}$}

\section{Paracelsus értékelése}

„P Paracelsus valóban nem volt gáncs nélküli lovag, sem szent életü aszkéta.”-mondja Schulteisz Emil.[24] Pozitív véleménnyel valóban csak néhány kortársa és követője (Theodor Zwinger(1533-1588), Oswald Croll, Johan Baptista van Helmont,(1580-1644) Daniel Sennert(1572-1637) volt róla. Főleg Angliában és Párizsban uralkodott vegyes vagy negatív vélemény személyéről és munkásságáról. Híveinek többsége a német, osztrák és svájci tudósok körében voltak fellelhetőek. Sajnos évszázadokkal később sem lehet teljesen tisztán eldönteni Paracelsus ellentmondásos személyének miben létét, olyan nagy szerzök munkáinak tükrében sem, mint Karl Sudhoff (1853-1938), Will Erich Peuckert (1895-1969), Kurt Goldammer (1916-1997), vagy Walter Pagel (1898-1983).[17]

Paracelsus sokszor logikátlan és nem mindig konzekvens a saját eszmefuttatásaiban sem. Gyakran változtatja a véleményét, impulzív, és sokszor dühösen inzultálja kortársait, ezenkívül nem kommunikál

(Forrás: https://p0.storage.canalblog.com/07/02/119589/112900728_o.jpg) 
Kaleido scope
Journal of History of Culture, Science and Medicine
2020. Vol. 10. No. 20 .

e-ISSN: 2062-2597

DOI: $10.17107 /$ KH.2020.20.17-29

egyértelmüen és tisztán. Müvei német vagy német-latin keveréknyelven íródtak, sokszor csak ötleteket vetett papírra. Előfordult, hogy csak később folytatta korábban megkezdett írásait, amiket nem vitt magával utazásaira. Nyelvezete rendkívül képi, ugyanakkor ingatag és pontatlan. Talán csak fiatalon tudott jól beszélni latinul. Számtalanszor nem hétköznapi szavakat választ és anélkül kezdi el használni ezen terminológiát, hogy megmagyarázná eredetüket vagy pontos jelentésüket, de ez egy nem teljesen szisztematikus és kaotikus életmü esetében talán nem is csoda.[17][18]

Megoldatlan kérdésnek tünik az is, hogy új gyógyszerei vajon hatékonyabbak voltak-e, mint az azt megelőzőek? Vajon nem voltak-e veszélyesebbek, és vajon kémiai gyógyszereik bevezetése valóban gazdagították-e az orvosi gyakorlatot abban az időben?

Lehet, hogy a paracelán tudás „,ikere” részben a rajongók, vagy a mester szónoki erejének hatása, esetleg kereskedők és az utazók útján vált ismerté, azonban ez ha igaz, ha nem, Paracelsus azon érdemén nem változtat, hogy egy új, szemléletmódot hozott be az orvostudományba.[17]

C.G. Jung értelmezése szerint erős kettősség hatja át Paracelsus személyiséget valamint munkásságágát. Egy hívő keresztény, aki orvosi etikáját is erre építi (irgalmasság, mint alapvető orvosi tulajdonság), emellett pedig egy alkimista filozófus is, aki a tudomány müvelője, s így bizonyos dolgokban ellentmond a vallásnak. Paracelsus ezt jól összetudja egyeztetni, ám néha felmerül a kétely benne „, pogány módra írok és mégis keresztény vagyok".[32] C. G. Jung szerint, ha valaki konfliktusba kerül önmagával és a tudattalanjával, akkor pszichikus jelenségek jelenhetnek meg az illetőnél. Ez megjelenhet szóáradat, óriási beszédkészség, vagy új ún. hatalmi szavak konstruálásával és használatával is, egy indulatos támadó közlési móddal párosítva. Ezen jellemzők pedig igazak Paracelsusra.[32]

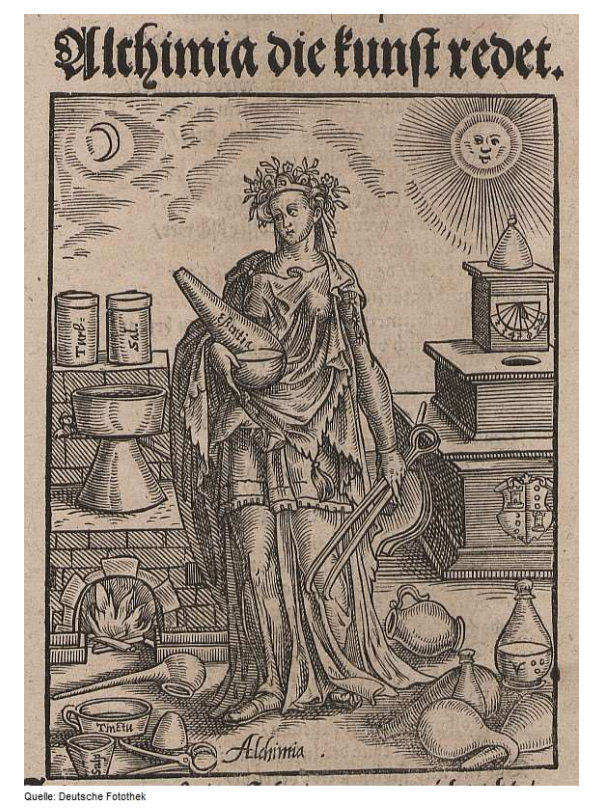

6. ábra Az alkímia allegóriája, kemencével, fújtatóval, desztillációs eszközökkel és szubsztanciákkal. (Leonhard Thurneysser Quinta Essentia)-ból ${ }^{6}$.

${ }^{6}$ (Forrás: https://upload.wikimedia.org/wikipedia/commons/c/c0/Fotothek_df_tg_0007034_Theosophie_\%5E_Alchemie.jpg) 
Kaleidosscope

Összefoglalva Paracelsus koncepcióját.

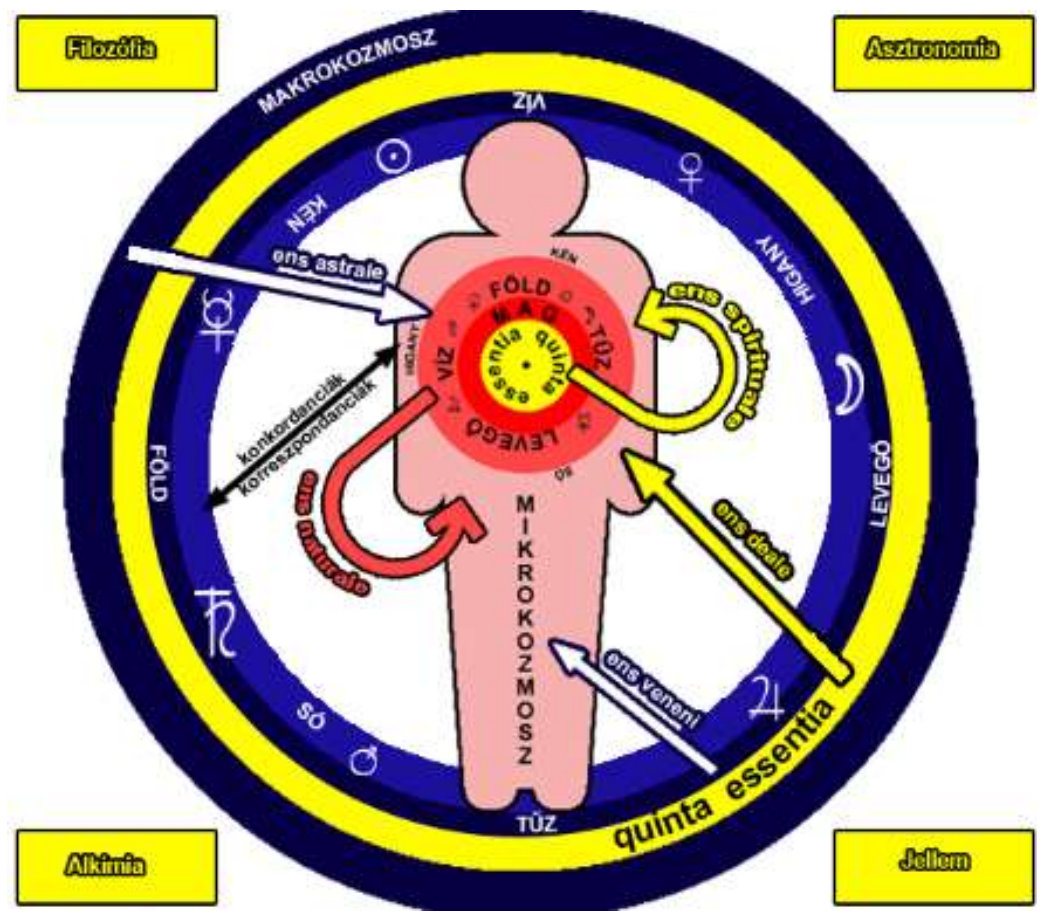

7. ábra Kísérlet Paracelsus világképének bemutatására a makro- és mikrokozmosz közötti konkordanciákkal, princípiumokkal és entitásokkal

Pogány alkimistai alapokon nyugvó keresztény és egyéb tudással kevert elméleti háttér. Az ember kettős lényü. Egy hallhatatlan isteni rész és egy földi, a természet részét képző "szerves anyag". A lét végső célja a lélek megtisztulása. A születéskori csillagászati konstelláció meghatározó az egyénre nézve. Az embernek van egy belső égboltja és van egy rajta kívüli. A különböző szervrendszerek kapcsolatban állnak a hozzájuk tartozó különböző égitestekkel illetve befolyásoltak azok által. A makrokozmosz befolyásolja a mikrokozmoszt. Az egészség, az anyagitest és a szellem együttes összhangjának eredménye. Amennyiben ez eltolódik, megbomlik valamilyen okból, betegség manifesztálódik.[32]

Tehát a gyógyítás során az egész embert kell nézni egészben. A leghatásosabb gyógymód mind testet mind lelket kell, hogy támogassa.

Paracelsusnál hangsúlyt kapott az emberi személyiség misztikumának megértése is, megelőzve korát ezzel a gondolattal (is).[32]

\section{Irodalomjegyzék}

1. https://www.spektrum.de/lexikon/biologie/iatrochemie/33574

2. RIDENOUR, Michael S: A Brief History of Chemistry 2010

3. DEMING, David Science and Technology in World History, Volume 4: The Origin of Chemistry, the Principle of Progress, the Enlightenment and the Industrial Revolution McFarland, 2016. $340 \mathrm{p}$.

4. WINDELSPECHT, Michael Groundbreaking Scientific Experiments, Inventions, and Discoveries of the 17th Century Greenwood Publishing Group, 2002 270p.

5. https://mek.oszk.hu/08700/08784/html/filozofia.htm

6. https://www.sciencehistory.org/distillations/al-kimiya-notes-on-arabic-alchemy

7. VAN Den Berk, M. F. M The Magic Flute Die Zauberflöte. An Alchemical Allegory 2004 650p 
8. ZIOLKOWSKI, Theodore Alchemist in Literature: From Dante to the Present, Oxford University Press, 2015. 240p. https://doi.org/10.1093/acprof:oso/9780198746836.001.0001

9. https://www.britannica.com/topic/philosophers-stone

10. EDSON, Gary Mysticism and Alchemy through the Ages: The Quest for Transformation McFarland, 2012 308p.

11. MADARÁSZ B,., . "Megment vagy elpusztít: a higany és arzén gyógyászati karrierje I. rész higany" Kaleidoscope 2019/18. https://doi.org/10.17107/KH.2019.18.210-240

12. DARMSTAEDTER, Ernst Die Alchemie Des Geber, Unikum 2013.

13. https://mult-kor.hu/vizeletbol-ezust-helyett-a-feny-hordozoja-a-foszfor-veletlen-felfedezesenek-trtenete20180824

14. https://www.britannica.com/biography/Paracelsus

15. MAGYAR, László András Paracelsus magyarországi recepciójáról, Kaleidoscope 2018/16 https://doi.org/10.17107/KH.2018.16.18-27

16. TARJÁN M. Tamás 1493. november 11. | Paracelsus születése, Rubicon http://www.rubicon.hu/magyar/oldalak/1493 november_11 paracelsus_szuletese/

17. RothSCHUH, Karl Ed. "Konzepte der Medizin in Vergangenheit und Gegenwart." (1978).p. 261-274

18. PARACELSUS Paragranum: az igaz gyógyítás oszlopai. ford. utószó, jegyz Adamik Lajos. Helikon, 1989.

19. https://mek.oszk.hu/00100/00176/html/ter.htm

20. GoOdRICK-Clarke, Nicholas, ed. Paracelsus. Vol. 1. North Atlantic Books, 1999.

21. PARACELSUS, Elementális lények. Könyv a nimfákról, szilfidekről, pigmeusokról, szalamandrákról és egyéb eleven teremtményekről Theophrastos Bombastus von Hohenheimtől., ford: Ladányi Lóránd. Miskolc, Hermit, 2001

22. http://rbx-exhibit2000.scs.illinois.edu/paracelsus.htm

23. ASCHNER, Bernhard, Paracelsus sämtliche Werke Jena Gustav Fischer, 1926

24. http://mek.oszk.hu/05400/05425/pdf/Schultheisz Theophrastus.pdf

25. HARTMANN, FranzThe Life and the Doctrines of Philippus Theophrastus, Bombast of Hohenheim Known by the Name of Paracelsus.Kegan Paul, Trench, Trübner \& Co. Ltd, London 1896

26. http://www.zeno.org/Philosophie/M/Paracelsus/Septem + Defensiones/Die + dritte + Defension + wegen + des + Schreibens + der + neuen + Rezepte

27. BORZELLECA, Joseph F. "Paracelsus: herald of modern toxicology." Toxicological Sciences 53.1 (2000): 2-4. https://doi.org/10.1093/toxsci/53.1.2

28. https://www.spektrum.de/lexikon/biologie/signaturenlehre/61530

29. https://www.encyclopedia.com/science/encyclopedias-almanacs-transcripts-and-maps/crollius-oswaldus$1580-1609$

30. https://dictionary.babylon-software.com/mercurius vitae/

31. Kurath, H., Middle English Dictionary (Vol.3.) University of Michigan Press. 1970

32. PÁtZaynÉ LiebermanN, Lucy: Paracelsica/ Jung, C. G. Magyar Pszichológiai Szemle 15. (1942) 124-126 